\title{
The Rate of Return to Educational Investment for Engineers: Evidence from the Private Sector in China
}

\author{
By Li Fengliang * \\ Li Manli ${ }^{\dagger}$ \\ W. John Morgan
}

It is well-known that engineering is a key profession for both economic and social development. This is as true for China as it is for other countries which are in the process of development. However, what are the economic incentives for young people to enter the profession today? Currently, there are many studies of the rate of return to educational investment, but recent empirical studies of the rate of return to educational investment for engineers are uncommon. This is true generally, but especially for contemporary China. This is because it is difficult to obtain high-quality and representative sample data about engineers. This paper uses the data of the Chinese Family Panel Studies, 2010, and applies a Mincerian income function to estimate the rate of return to education for engineers who work in the private sector in urban China. The empirical results show that the rate of return for engineers is $12.3 \%$, which is an impressive figure. It is in accordance with the current supply and demand of the Chinese labour market which requires many engineers to carry out construction and maintenance projects given China's continuing industrialisation, modernisation and urbanisation. However, the empirical results also show that compared with the rate of return to education for professional and technical personnel who are employed in business economics and finance, the rate of return for engineers is significantly lower. This may explain why in China today the attraction of engineering education for talented young people is declining, with more and more students choosing business economics and finance as their first choices of major and career, rather than engineering as in the past.

Keywords: Rates of Return to Education; Engineering; Private Sector; China

\section{Introduction}

It is well-known that engineering is a key profession for both economic and social development and that it is vital to a sustainable future. In a recent blog for the development website Devex Newswire, Judith Rodin, the president of the Rockefeller Foundation and formerly president of the University of Pennsylvania, and provost of Yale University, reminded us that: "...natural disasters, resource constraints and new patterns of development require

\footnotetext{
* Associate Professor, Institute of Education, Tsinghua University, Beijing, China.

${ }^{\dagger}$ Professor, Institute of Education, Tsinghua University, Beijing, China.

* Emeritus Professor \& Senior Fellow, China Policy Institute, University of Nottingham; Honorary Professor, School of Social Sciences, Cardiff University.
} 
companies and governments to plan for energy and other related infrastructure to be both resilient and sustainable" (Rodin, 2015). This can only be achieved through educating and training accomplished engineers across the range of the profession. This is also why the British Royal Academy of Engineering has established the Africa Prize for Engineering Innovation which aims to stimulate, celebrate and reward innovation and entrepreneurship among the profession in sub-Saharan Africa. The Africa Prize encourages ambitious and talented sub-Saharan African engineers from all disciplines to apply their skills in developing practical solutions to local challenges, highlighting the importance of engineering as an enabler of improved quality of life and economic development (Royal Academy of Engineering, 2015).

Such challenges and professional expertise are obviously of particular importance to developing economies and societies in transition. As a recent study of professional education in post-socialist Serbia noted, modern states and societies are based on trained expertise. It commented that: "....professionalised societies are thus based on human capital hierarchies and closure, that is to say, the exclusion of the non-qualified. A profession is generally thought to be of higher value than a mere occupation or job. It involves a very long process of education and is esteemed by society, whereas an occupation implies mainly practical skills which are acquired after relatively low levels of basic education" (Kaurin \& Morgan, 2014, p. 59). These are both economic and sociological distinctions and the engineering profession has been (and is) a key example throughout all stages of modernization.

It is clear that similar challenges and social changes face contemporary China. In 1949, when the People's Republic of China was founded, the Chinese Communist Party and State attached great importance to engineering construction in order to recover from many years of war and weakness; and engineering education became one of the top issues on the agenda of the Chinese leadership. Consequently engineering became a profession of high reputation in the opinion of Chinese people. Because of their excellent performance on the frontline of the country's development projects, many engineers were promoted to positions of prominence. This trend was enhanced in the years following the Cultural Revolution (1965-1969) during which engineering education and higher education generally was neglected drastically. A comprehensive and still useful set of analyses of science and technology in post-Mao China, published in 1989, by American scholars familiar with China, identified the serious shortcomings that held back the country's development as it entered the period of economic reform and "Opening Up" initiated by Deng Xiao Ping in the same year (Simon \& Goldman,1989).

A key problem identified was the lack of trained engineers and support technicians, aggravated by poor standards of education in vocational and technical secondary schools, with many young people preferring secondary general schools. A further problem was the long educational cycle which left trained engineers at a premium in the emerging labour market (Orleans, 1989, p.116). Again, as Grow pointed out, engineers had (and still have) a key role to play in technology acquisition, transfer, and utilization, especially that being 
brought to China from outside the country. The relationship of engineers with the management of enterprises and other users of technology was (and still is) a vitally important ingredient in economic development (Grow, 1989, p.344). It was noted also that engineers, with their disposition towards technical efficiency, and often from backgrounds in heavy industry and the defence sector, were becoming more prominent in the Chinese Communist Party and State élite (Suttmeier, 1989, p.382). It is a fact that from the 1990s until now, many key leaders in the Chinese government have been engineers or with a strong education background in engineering. JIANG Zemin, ZHU Rongji, HU Jintao, WEN Jiabao ${ }^{1}$ are notable examples. Such people were key figures as economic development and infrastructure construction became core tasks for the Chinese Government. The strong and continuing economic growth of China since 1990, its rapid industrialisation and urbanisation, as well as the number of infrastructure projects, have combined to make engineering a favoured profession, with engineering education still a first choice of many outstanding students.

Since the beginning of the new century China's economy has continued to grow steadily, a pattern which it is forecast may be sustained until 2020 (Fogel, 2008). However, there is a paradoxical trend that the social status and the reputation of engineers is declining, with engineering education becoming less attractive to talented young people. For example, in Tsinghua University, the most prominent university for engineering education in China, more and more students choose business and finance as their first choices rather than engineering subjects in the past.

It is worth noting that such a situation also exists elsewhere, for example in the United States. The difficulty in attracting high school graduates to engineering, together with the high drop-out rate of engineering students, are common causes of the decline in the number of engineering students. The result is that during the 1990s the annual graduation rate of engineering graduates in the United States declined dramatically by 20\%; although the number of engineering jobs in the labour market increased by a big margin (Felder, Felder, \& Dietz, 1998). In fact, the substantial decline in the number of engineering graduates in the United States began as early as in the mid-1980s, but the gap was filled by high-quality immigrants (Romer, 2000).

The paradox is that, while the Chinese economy is developing rapidly, the attractions of engineering education and the profession of engineer for young people are declining. So why does this happen? This paper will attempt to explain this phenomenon through examining the rate of return to educational investment for engineers in the context of China's growing economy, specifically the private sector, and by comparing the rate of return to educational investment with that for those employed in business and finance.

\footnotetext{
${ }^{1}$ They were President, Prime Minister, President, and Prime Minister of the People's Republic of China respectively.
} 


\section{Literature Review}

\section{The Engineers in the Private Sector}

It is important to note the following: First, there are significant differences in the rate of return to educational investment between the private and the public sector in China; since the wage in the private sector can reflect productivity, while the wage in the public sector is determined by the bureaucratic system (Li \& Ding, 2003). Secondly, Li and Li (2010) found that the rate of return to schooling is rather low for engineers in the Chinese public sector. If the rate of return to education should also prove to be low for engineers in the Chinese private sector, then stakeholders should consider how to improve the rate of return for engineers so that engineering education can attract more talented young people. Finally, the private sector has been developing rapidly and attracting more and more Chinese engineers. For these reasons, it is necessary to investigate the return to education for engineers in the private sector.

With economic reform and "Opening Up", the private sector has grown significantly in China and attracts more and more employees. Between 2004 and 2010, the number of employees in the private sector almost doubled from 88 million to 162 million; while the number of employees in the public sector decreased slightly, from 76 millions to 71 millions. The scale of employment in the industries of the private sector also increased dramatically. For example, the number of employees in the manufacturing industries of the private sector increased from 26 million in 2004 to 42 million in $2010^{2}$.

\section{The Rate of Return to Educational Investment}

International interest in the rate of return to educational investment began in the late 1950s. At that time numerous studies of the rate of return to educational investment were used to support the human capital theory that education, as a type of important human capital, enhanced individual capacity for labour productivity. Such studies become the theoretical framework used by many countries to stimulate national economic growth through the expansion of educational provision. Moreover, comparative studies of the rates of return to educational investment for different disciplines and occupations have been used as guidance for individuals about the choice of majors at university or about their future profession. This literature is very well known and will not be reconsidered here. However, a relatively recent commentary on the rate of individual return to educational investment in China identified certain features. First, it has increased with the expansion of educational provision since the 1980s. Secondly, the greater the individual educational opportunity available, the larger is the rate of return, which favours those living in urban areas rather than those living in rural areas. Fourthly, the rate of return

\footnotetext{
${ }^{2}$ The data is calculated by the authors from the data given on the official website of the National Bureau of Statistics of the People's Republic of China. http://bit.ly/2laaAow (accessed $17^{\text {th }}$ May, 2015).
} 
in the public sector is greater than that in the private sector. Meanwhile, from an international comparative perspective, it is commented that possible explanations of the above are: a history of élite education and of a screening culture; the rapid transition from a planned economy to a market economy; and the continued segmentation of the labour market in China (Li, Zhao, \& Morgan, 2011).

\section{The Rate of Return to Investment in Engineering Education}

There are several studies of the rate of return to education for the engineering education (as a discipline) internationally (for example: Vaillancourt, 1995; Bourne \& Dass, 2003; Finnie \& Frenette, 2003; Darmody, Smyth, \& Unger, 2008). However, there are relatively few empirical studies on the rate of return to educational investment for engineers (as an occupation), as it is very difficult to obtain high-quality and representative samples of engineers (Lassibille, 2001).

In our literature search we found only the following papers that studied empirically the rate of return to educational investment for engineers: Wilson (1980) surveyed British engineers, Lassibille (2001) Spanish engineers and Bonnarda, Bourdona and Paula (2009) French engineers. In China, there is a recent study ( $\mathrm{Li} \& \mathrm{Li}, 2010$ ) which estimated empirically the rate of return to education for engineers using the data obtained from a pilot survey. This found that such a rate of return was significantly less than the national average. However, the data used was not subject to a rigorous random sampling design, but only to convenience sampling. Moreover the survey samples were limited to engineers in the power, railway and petrochemical industries in the public sector in Beijing, Xi'an, Lanzhou and Daqing. It is necessary to use higher quality and more representative data to analyse this issue more accurately.

This paper will estimate the rate of return to education for engineers in China using a rigorous sampling method and representative nationwide survey data. It will also compare engineers with professional and technical personnel who work in the business and financial sectors. This will be a compensation for the lack of empirical research on this issue and offer an answer to the question of why more and more outstanding students give up engineering subjects or an engineering career, but choose business economics and finance as their first choices instead. The rest of the paper is organized as follows: the next part explains the method used to estimate the rate of return to engineering education; the third part describes the data used; the fourth part presents and discusses the empirical findings; and the final part presents some conclusions, including suggestions for further research.

\section{Method}

There are two categories of rate of return to educational investment: the private rate of return and the social rate of return. This paper focuses on the former. Currently, there are two methods used to measure the private rate of 
return to education. One is the Mincerian rate of return, which is the marginal rate of return and reflects the percentage increase in earnings resulting from an additional year of schooling. The other is the internal rate of return, which is obtained by making the discounted present value of long-term costs and returns to zero and calculating the internal discount rate.

Calculating the internal rate of return requires information about the individual's educational investment that is extremely difficult to obtain. As a result, there are fewer studies on the internal rate of return and more on the Mincerian rate of return. Each of the four papers analysing the rate of return to educational investment for engineers mentioned above calculated the Mincerian rate of return (Wilson, 1980; Lassibille, 2001; Bonnarda, Bourdona, \& Paula, 2009; $\mathrm{Li} \& \mathrm{Li}, 2010)$. Therefore, this paper will estimate the Mincerian rate of return to engineering education in China.

The Mincerian rate of return will be estimated using the Mincerian income function. This is a method used to calculate the rate of return to educational investment proposed by Jacob Mincer, one of the pioneers of human capital theory. Consider the following equation:

$$
\operatorname{Ln} Y=\alpha+\beta * S+\gamma_{1} * E X+\gamma_{2} * E X^{2}+\xi
$$

This is where $\operatorname{LnY}$ is the natural logarithm of the income of individual worker, $S$ represents the years of education of the individual worker, while $E X$ represents the years of work experience of the individual worker. By this simple mathematical formula it can be inferred that the economic meaning of $\beta$, the coefficient of years of education (with the assumption that the direct educational cost is zero and the educational cost is mainly the opportunity cost of giving up the job opportunity) is that $\beta$ stands for the percentage increase of an individual worker's income through taking one extra year of education or the Mincerian rate of return. Therefore, the Mincerian rate of return is a marginal concept. This paper uses the individual worker's income, educational background, and work experience and, using the Mincerian income function estimates the Mincerian rate of return.

\section{Data}

Lassibille (2001) considers that one of the major reasons why there are relatively few studies analysing the rate of return to educational investment for engineers is that there is a lack of high-quality data for such a sample. This is because the occupation codes in the majority of survey questionnaires for individual workers are only designed as a one-digit code or a two-digit code. This makes it very difficult to measure the relationship between education and income for different occupations, as only a three-digit code can achieve this goal (Riley, 1979). More importantly, by adopting a one-digit code or a twodigit code to collect data on an occupation, it may be impossible to separate the sample of engineers from the whole sample. This is because engineers are 
always classified as professional and technical personnel, such as teachers, doctors, and those employed in business economics and finance. However, if a three-digit code is used to collect the data, then engineers can be separated from other professional and technical personnel.

The data used in this paper was obtained from the Chinese Family Panel Studies (CFPS) conducted by the Institute of Social Science Survey, Peking University in 2010. The most remarkable feature of this data is that it applies a three-digit occupation code to collect occupational information about the samples. This means that it classifies the occupation of engineering in a more detailed way. Therefore, through applying the Mincerian income function we are able to estimate the rate of return to education for engineers. The targets of the Chinese Family Panel Studies 2010 (CFPS) were all family members in 25 provinces, cities and autonomous regions of China (excluding Hong Kong, Macau, Taiwan and Xinjiang Uyghur Autonomous Region, Tibet Autonomous Region, Qinghai Province, Inner Mongolia Autonomous Region, Ningxia Hui Autonomous Region and Hainan Province). The sampling method used was a three-stage cluster sampling design, which obtained sample counties and sample communities, as well as sample families ${ }^{3}$. The raw data questionnaire of the CFPS2010 was comprised of five parts namely: community, family members, household, adults (over 16 years) and children. In order to make it easier for researchers to use the data, the Institute of Social Science Survey, Peking University divided the raw database similarly into five parts: community database, family relationship database, family database, adult database and child database. In this paper we use the adult database.

Above we cited four studies which analysed empirically the rate of return to investment in engineering education. Three calculated the rates of return in the private sector, excluding the samples of engineers in the public sector (Wilson, 1980; Lassibille, 2001; Bonnarda, Bourdona, \& Paula, 2009). Li and Li (2010) used a sample of workers in the public sector as they had no other choice given the availability of data. However, studies show that there are significant differences between income and the rate of return to educational investment for the public sector and the private sector. This is because the income system of the public sector is favourable to seniority and does not reflect workers' actual productivity (Lee \& Miller, 2004; Heywood \& Wei, 2004). Hence, the sample of the private sector is generally used alone to estimate the rate of return to educational investment. In addition, there is significant urban-rural labour market segmentation and a huge gap between the income and expenditure of the urban and rural areas in China. Therefore, in China most studies of the rates of return to educational investment for urban area and rural area are estimated separately. Even the National Bureau of Statistics of China has two different departments which consider the residents of urban and rural households separately. Accordingly, this paper will only examine samples of adult urban residents who work in the private sector.

\footnotetext{
${ }^{3}$ The detail of the sampling methods used by the CFPS 2010 may be found on the official website of the Institute of Social Science Survey, Peking University at: http://www.isss.edu.cn/ (accessed $17^{\text {th }}$ May, 2015).
} 
Table 1 is a simple statistical description of each variable, where $\mathrm{Ln}$ income is the natural logarithm of the monthly income of the sample, Edu is the years of schooling, Age is the age and Age2 is the age squared. Here we use age instead of working experience because there is no information available on working experience in the data used, and this is the current practice of many similar studies.

In the CFPS2010 there were 33610 adult samples in total, 7258 of which were urban households. Among these 7258 samples, there were 3142 samples who worked in the private sector. As the majority of the population in China lives in rural households, while the public sector is still relatively powerful, it was not surprising to see the sample size shrink to only 3142 . Some of the 3142 samples lack information ${ }^{4}$ on years of schooling and income, which are essential for the estimation of the rate of return to educational investment. Therefore, there were only 2877 usable samples for our purposes, of which 257 samples were within the broad category of professional and technical personnel, with 112 samples of engineers and 69 samples of those employed in business and finance. These were used for our analysis.

Table 1. Simple Statistical Description of Variables

\begin{tabular}{|l|c|c|c|c|c|c|c|c|}
\hline & \multicolumn{3}{|c|}{ All } & \multicolumn{2}{c|}{$\begin{array}{c}\text { All Professional } \\
\text { Personnel }\end{array}$} & \multicolumn{2}{c|}{ Engineer } & \multicolumn{2}{c|}{$\begin{array}{c}\text { Economics and } \\
\text { Finance }\end{array}$} \\
\cline { 2 - 10 } & Mean & S.D. & Mean & S.D. & Mean & S.D. & Mean & S.D. \\
\hline $\begin{array}{l}\text { Lninco } \\
\text { me }\end{array}$ & 7.306 & 0.663 & 7.667 & .7518 & 7.867 & 0.720 & 7.927 & 0.601 \\
\hline Edu & 9.297 & 3.683 & 12.737 & 2.932 & 12.692 & 3.281 & 13.036 & 2.427 \\
\hline Age & 36.396 & 10.91 & 34.237 & 10.26 & 33.241 & 9.275 & 35.667 & 9.872 \\
& & 8 & & 6 & 1 & & & \\
\hline Age2 & 1443.8 & 854.6 & 1277.1 & 810.5 & 1190.2 & 687.4 & 1368.1 & 795.8 \\
& 19 & 11 & 87 & 39 & 23 & 67 & 60 & 49 \\
\hline N & \multicolumn{2}{|c|}{2877} & \multicolumn{2}{|c|}{257} & \multicolumn{2}{c|}{112} & \multicolumn{3}{c|}{69} \\
\hline
\end{tabular}

\section{Empirical Findings and Discussions}

Table 2 below gives the regression result of Mincerian income function using both the sample of engineers and the sample of professional and technical personnel employed in business and finance. It can be observed from Column 1 Table 2 that the coefficient of years of education is 0.063 and is significantly positive. This indicates that the rate of return to education for all samples of employees working in the private sector in Chinese cities and towns is $6.3 \%$. In other words, by receiving one extra year of education, the incomes of employee who are registered urban residents and working in the private sector will increase by $6.3 \%$, which is significant.

It can be seen from Column 2 in Table 2 that the rate of return to education for all professional and technical personnel including engineers is $10.3 \%$. This

\footnotetext{
${ }^{4}$ These samples include those students who are still at college and the unemployed.
} 
is basically the same as the average rate of return to educational investment worldwide (Psacharopoulos \& Patrinos, 2004). Column 3 shows that the rate of return to education for engineers is $12.3 \%$, which is higher than the average rate of return to educational investment for all professional and technical personnel. This is in accordance with the current supply and demand in the Chinese labour market, which requires many engineers for construction and maintenance, especially in fast-developing urban areas. However, the rate of return to educational investment for professional and technical personnel in business and finance, shown in Column 4 , is higher at $14.2 \%$.

Table 2. The Regression Result of Mincerian Income Function

\begin{tabular}{|l|c|c|c|c|}
\hline & $\begin{array}{c}\text { Column 1 } \\
\text { All }\end{array}$ & $\begin{array}{c}\text { Column 2 } \\
\text { All Professional } \\
\text { Personnel }\end{array}$ & $\begin{array}{c}\text { Column 3 } \\
\text { Engineer }\end{array}$ & $\begin{array}{c}\text { Column 4 } \\
\text { Economics and } \\
\text { Finance }\end{array}$ \\
\hline \multirow{2}{*}{ Constant } & 5.803 & 5.322 & 5.178 & 6.229 \\
\cline { 2 - 5 } & $(0.124) * * *$ & $(0.498) * * *$ & $(0.788) * * *$ & $(0.888) * * *$ \\
\hline \multirow{2}{*}{ Edu } & 0.063 & 0.103 & 0.123 & 0.142 \\
\cline { 2 - 5 } & $(0.003) * * *$ & $(0.015) * * *$ & $(0.018) * * *$ & $(0.031) * * *$ \\
\cline { 2 - 5 } Age2 & 0.048 & 0.046 & 0.044 & -0.040 \\
\cline { 2 - 5 } & $(0.006) * * *$ & $(0.025) * * *$ & $(0.023) *$ & $(0.045)$ \\
\hline $\begin{array}{l}\text { Adjusted } \\
\mathbf{R}^{2}\end{array}$ & -0.001 & -0.0004 & -0.001 & 0.001 \\
\hline $\mathbf{N}$ & 0.137 & $(0.0002) *$ & $(0.0004) * *$ & $(0.001)$ \\
\hline
\end{tabular}

Note: Standard errors are presented in parentheses. "***": significant at the $1 \%$ level; "**": significant at the 5\% level; "*": significant at the $10 \%$ level.

Using further statistical tests, the empirical results showed that the difference between the rates of return to educational investment for different sample groups in Table 2 was statistically significant. In other words, compared with the rate of return to educational investment for professional and technical personnel in business economics and finance, the rate of return to educational investment for of engineers was significantly lower. This is an explanation why engineering education is becoming less attractive to talented young people in China today, with more of them choosing business economics and finance as their first choices when selecting majors at the university, rather than engineering as in the past. Many excellent engineering graduates are also choosing to change to jobs related to business economics and finance, as, for example, several star fund managers in China who obtained higher education degrees in engineering initially. This is another trend which may be observed internationally.

It can be observed from Table 1 that the average number of years of education for engineers was 12.692. The average number of years of education for professional and technical personnel who engage in business economics and finance was 13.036 years, which was 0.3 years more than that of engineers. By using a further statistical test, we noticed that this difference was again statistically significant. It showed that the average years of education of 
engineers was significantly lower than that of professional and technical personnel in business economics and finance. This indicates that more people with higher education engage in business economics and finance rather than in engineering. In addition, the coefficients of each variable in Column 1-3, Table 2 were consistent: the coefficients of years of education and age were positive and the coefficient of age squared was negative. This is completely in accordance with the regression results of the classical Mincerian income function, showing that the individual's income increases with each year of education, work experience or age. However, when work experience or age approaches a value of retirement, the individual's income will be reduced with the increase in work experience or age.

However, Column 4 in Table 2 shows that the coefficient of the age of professional and technical personnel in business economics and finance was negative, which is not in accordance with the classical pattern. It indicates that older individuals or individuals with more work experience are in a disadvantageous rather than an advantageous position regarding income. This suggests that business economics and finance are more rewarding for young people and explains why students of talent choose these subjects as their majors at university and as careers when they graduate. It is also the case, as we observed above, that many of those who graduate as engineers look for jobs in finance in which they can utilize their quantitative skills. This is not exceptional to China.

\section{Conclusions}

Empirical studies of the rate of return to educational investment to engineers will help policy makers determine the scale of financial support for engineering education (Psacharopoulos \& Patrinos, 2004). They will also enhance decisions about selection of higher education in engineering by students (Romer, 2000). However, as we have said, it is not easy to obtain high-quality and representative samples of engineers for such studies. By using the data of the CFPS2010, this paper analysed empirically the rate of return to educational investment for engineers who work in the private sectors of cities and towns in China. The most distinctive feature of this data is that it adopted a 3-digit occupation code to collect information on the samples' occupations. This enabled us to separate not only the samples of engineer from other professional and technical personnel, but to place them alongside the samples of professional and technical personnel in business economics and finance.

The empirical results showed that the rate of return to educational investment for engineers is $12.3 \%$. This is higher than the average rate of return to educational investment for all professional and technical personnel, which is $10.3 \%$. It shows that the rate of return to educational investment for engineers who work in the private sector is relatively high, which is consistent with the active demand for engineers in the Chinese labour market. However, the empirical results also show that, compared with the rate of return to educational 
investment for professional and technical personnel in business economics and finance, the rate of return to educational investment for engineers was significantly lower by nearly $2 \%$. This may explain why in China today the attraction of engineering education to talented young people is less than that in business economics and finance and related occupations. And it is a popular phenomenon in many developed countries. A future research topic should be to discover a strategy to attract more young people to engineering programs.

The rate of return to educational investment for engineers who work in the private sector in China is still relatively high. However, with the continuing expansion of the higher education in China and the potential slowdown of construction of infrastructure, will the rate of return to educational investment for engineers change? Further empirical studies examining changes in the rate of return to educational investment for engineers in China are required and over a longer period, say ten years. In addition, there are already studies examining engineers' job satisfaction (Bonnarda, Bourdona, \& Paula, 2009). It would be informative to examine the relationship between engineers' incomes and their job satisfaction in further studies, together with studies considering the impact of their regional distribution across China.

\section{Acknowledgement}

The paper received the support of the "The study on accelerating the convergence of higher engineering education professional accreditation system and engineers' registration system" sponsored by the consulting research project of the Chinese Academy of Engineering (Project No. 2014-12-XY-003).

\section{References}

Bonnarda, C., Bourdona, J., \& Paula, J. (2009). French engineering graduates in corporate R \& D: is it worthwhile? European Journal of Engineering Education, 34(6), 593 $-603$.

Bourne, C., \& Dass, A. (2003). Private and social rates of return to higher education in science and technology in a Caribbean economy. Education Economics, 11(1), 1-10.

Darmody, M., Smyth, E., \& Unger, M.(2008). Field of study and students' workload in higher education: Ireland and Austria in comparative perspective. International Journal of Comparative Sociology, 49(4-5), 329-346.

Felder, R. M., Felder, G. N., \& Dietz, E. J. (1998). A longitudinal study of engineering student performance and retention: Comparisons with traditionally-taught students. Journal of Engineering Education, 87(4), 469-480.

Finnie, R., \& Frenette, M. (2003). Earning differences by major field of study: evidence from three cohorts of recent Canadian graduates. Economics of Education Review, 22(2), 179-192.

Fogel, R. (2008). Why China is likely to achieve its growth objectives. In G. G. Liu, S. Zhang and Z. Zhang (Eds.). (2010). Investing in Human Capital for Economic Development in China (3-18.. Singapore: World Scientific Publishing Co. Pte. Ltd. 
Grow, R.F., (1989). Acquiring foreign technology: What makes the transfer process work? In: D. F. Simon and M. Goldman (Ed.), Science and Technology in PostMao China (pp.319-346). Cambridge, Massachusetts and London: Harvard University Press.

Heywood, J. S., \& Wei, X. D. (2004). Education and signaling: Evidence from a highly competitive labor market. Education Economics, 12(1), 1-16.

Kaurin, D., \& Morgan, W. J., (2014). The changing expectations of education for the professions in post-socialist Serbia: The views of lawyers and of university teachers. International Journal of Continuing Education and Lifelong Learning, $6(2), 59-74$.

Lassibille, G. (2001). Earnings distribution among Spanish engineers: research versus non-research occupations. Research Policy, 30(4), 673-680.

Lee, Y. L., \& Miller, P. W. (2004). Screening and human capital in the Australian labor market of the 1990s. Australian Economic Papers, 43(2), 117-135.

Li, F. L., \& Ding, X. H. (2003). A Test of the Educational Contribution to Augmenting Productivity in China. Tsinghua Journal of Education, 5(2003), 4145 .

Li, F. L., \& Li, M. L. (2010). An empirical study of the rate of return to education for engineers. Research in Higher Education of Engineering, 5(2010), 37-42. [in Chinese].

Li, F., Zhao. Y., \& Morgan, W. J. (2011), The rate of return to educational investment in China: A Comparative Commentary. Education, Knowledge and Economy, 5(1-2), 45-52.

Orleans, L. A. (1989). Reforms and innovations in the utilization of China's scientific and engineering talent: In D. F. Simon \& M. Goldman (Ed.), Science and Technology in Post-Mao China (pp. 89-118). Cambridge, Massachusetts and London: Harvard University Press.

Psacharopoulos, G., \& Patrinos, H. A. (2004). Returns to investment in education: A further update. Education Economics, 2(2), 111-134.

Riley, J. G. (1979). Testing the educational screening hypothesis. Journal of Political Economy, 87(5), 227-252.

Rodin, J. (2015). Engineering the next 100 years of resilient infrastructure. Devex Newswire, $29^{\text {th }}$ April 2015.

Royal Academy of Engineering. (2015). Africa Prize for Engineering Innovation. Retrieved April 30, 2015 from http://bit.ly/1TBYnRE.

Romer, P. M. (2000). Should the government subsidize supply or demand in the market for scientists and engineers? Innovation Policy and the Economy, 1, 221252.

Simon, D. F., \& Goldman, M. (Ed.). (1989). Science and Technology in Post-Mao China. Cambridge, Massachusetts and London: Harvard University Press.

Suttmeier, R. P. (1989). Conclusion: Science, technology, and China's political futureA framework for analysis. In D. F. Simon \& M. Goldman (Ed.), Science and Technology in Post-Mao China. Cambridge, Massachusetts and London: Harvard University Press.

Vaillancourt, F. (1995). The private and total returns to education in Canada. The Canadian Journal of Economics, 28(3), 532-554.

Wilson, R. A. (1980). The rate of return to becoming a qualified scientist or engineer. Scottish Journal of Political Economy, 27(1), 41-61. 